\title{
20. PALEOMAGNETIC RESULTS FROM HOLES 959D AND 960A, CÔTE D'IVOIRE-GHANA TRANSFORM MARGIN'
}

\author{
Simon Allerton ${ }^{2}$
}

\begin{abstract}
This paper reports paleomagnetic results from minicores taken from Ocean Drilling Program Holes 959D and 960A, drilled on the marginal ridge of the Ghana-Côte d'Ivoire Transform Margin. As initially indicated by shipboard studies, many samples were too weak to measure, and many that were measurable did not carry a stable remanence. Despite these problems, a significant number of reliable measurements were obtained from three units: Unit III of Hole 959D, and Subunits IVB and VB of Hole 960A. The sediments from Unit III of Hole 959D and Subunit IVB of Hole 960A appear, from formation microscanner data and seismic reflection profiles, to dip gently north-northwest, away from the marginal ridge. In the absence of any other method of reorienting the data from core to geographic coordinates, the data from these units were reoriented by rotating the dip-direction measured in the core to the regional dip direction (assumed to be $330^{\circ}$ ).

Stable magnetizations from Unit III of Hole 959D probably represent the combination of steep drilling-induced overprints, and shallow, generally northerly directed components that may correspond to either a recent overprint or an earlier magnetization.

The limited number of reliable directions from Subunit IVB of Hole 960A have shallow inclinations, and are dominantly directed to the north after the azimuthal correction is applied. It is not possible to discriminate whether this component was formed before or after tilting. Subunit VB of Hole 960A lies beneath an angular unconformity. A different approach was applied to the stable components of these rocks: the stable component was rotated to a common direction (assumed north), and the resulting bedding orientations were considered. Results can either be interpreted as folding about an axis orthogonal to the marginal ridge, or a sequence of reversals. The former is considered more likely.
\end{abstract}

\section{INTRODUCTION}

Transform continental margins are poorly understood compared to either rifted or subduction-zone margins. Their evolution likely involved an initial phase of intracontinental transform faulting, an ocean-continent transform stage, and, after the passage of the opposite ridge past the margin, a passive subsidence stage, similar to that experienced by passive margins (Scrutton, 1979). The structural history of transform margins is of considerable interest, as it illuminates the larger scale tectonic processes that controlled their development. Leg 159 addressed issues of transform-margin evolution by drilling at the Ghana-Côte d'Ivoire margin, where the Romanche Fracture Zone meets the West African coast (Mascle, Lohmann, Clift, et al., 1996). Shipboard studies indicated the nature and relative timing of the structures, but two important questions remained unanswered: What was the orientation of the structures within the core? Was the section affected by vertical axis rotations? This latter question is particularly interesting given the common occurrence of rotations associated with continental transform faults (e.g., Luyendyk et al., 1985; Ron et al., 1984). In addition, many sections within the deeper holes are barren, and additional age constraints provided by magnetostratigraphy would be extremely useful.

\section{Geological Setting}

The Côte d'Ivoire-Ghana Transform Margin lies in the eastern equatorial Atlantic, where the Romanche Fracture Zone meets the western coast of Africa. Leg 159 concentrated on the marginal ridge, a broad high that parallels the transform margin (striking $060^{\circ}$ ), and forms the southern boundary of the deep Ivorian Basin (Fig. 1). This

${ }^{1}$ Mascle, J., Lohmann, G.P., and Moullade, M. (Eds.), 1998. Proc. ODP, Sci. Results, 159: College Station, TX (Ocean Drilling Program).

${ }^{2}$ Department of Geology and Geophysics, University of Edinburgh, West Mains Road, Edinburgh EH9 3JW. Simon.Allerton@glg.ed.ac.uk margin has been the focus of several marine cruises conducting gravimetry, seismic reflection, and refraction, as well as submersible cruises, before Leg 159 (Emery et al., 1975; Blarez and Mascle, 1988; Mascle et al., 1993).

Rifting probably commenced in Neocomian-Aptian times, and rifting and transform slip probably ceased by Albian times. Final separation between West Africa and Brazil probably occurred in Santonian time. The passive-margin stage followed the passage of the marginal ridge in Late Cretaceous times (Blarez and Mascle, 1988).

\section{Project Objectives}

The objective of this study was to use paleomagnetic measurements to constrain the structural evolution of the Côte d'IvoireGhana Transform Margin. The principal intention was to use the paleomagnetic data to reorient structural measurements made on the cores relative to a paleomagnetically defined reference frame. The second objective was, where possible, to combine the data with independent constraints on the orientation, such as those provided by formation microscanner (FMS) log data, or by determinations of regional dip directions, to identify rotations about vertical axes which might be associated with the transform margin. A third objective was to determine the magnetostratigraphy, so that the age of barren zones could be constrained.

Paleomagnetic studies undertaken during Leg 159 (Mascle, Lohmann, Clift, et al., 1996) were dogged by problems resulting from weakly magnetized rocks and drilling-induced remagnetizations. It was hoped that the increased sensitivity and magnetically cleaner environment offered by shorebased paleomagnetic laboratories would allow the problems encountered during the leg to be overcome, and for stable remanent magnetizations to be identified. To a certain extent this objective has been achieved, although a large number of samples proved to be too weakly magnetized to successfully measure and demagnetize. 
Figure 1. Simplified structural sketch map of the Côte d'Ivoire-Ghana marginal ridge and surroundings (after Mascle, Lohmann, Clift, et al., 1996). Depth is shown in two-way traveltime to the top of the syn-rift seismic stratigraphic unit. Leg 159 sites are shown.

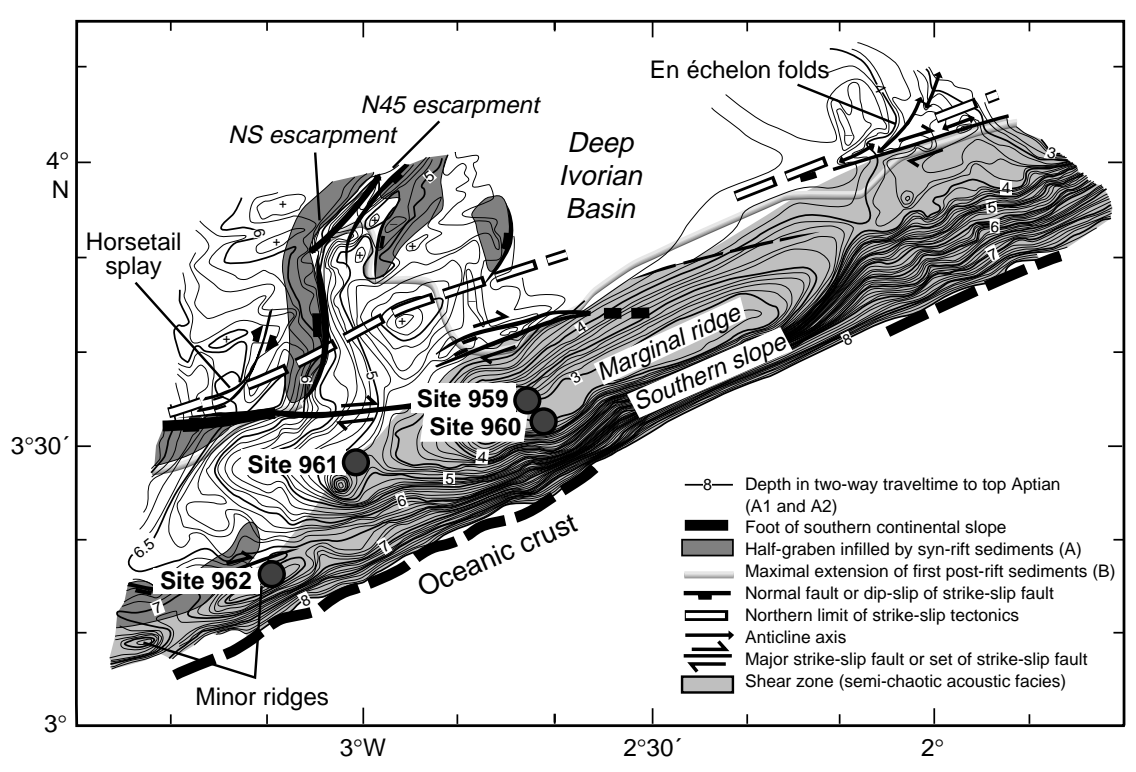

It was hoped that FMS data could be acquired for large sections of the core, which would allow a large body of the core to be independently reoriented. In fact, due to hole overwidening problems, the areas of the holes covered by FMS data were limited, so that no systematic reorientation scheme could be applied.

\section{DATA ACQUISITION}

Samples were taken from pieces having unequivocal orientation with respect to the vertical. Where possible, samples were taken from pieces with identifiable bedding. Lithified rocks were cut into cubes and unlithified sediments were pressed into plastic boxes. The orientation scheme is that described in Mascle, Lohmann, Clift et al., (1996). Paleomagnetic measurements were undertaken in the Department of Earth Sciences at the University of Oxford using a CCL cryogenic magnetometer and in the Department of Geology and Geophysics at the University of Edinburgh using a $2 \mathrm{G}$ cryogenic magnetometer. The maximum effective sensitivity of the CCL magnetometer is approximately $2 \times 10^{-5} \mathrm{~A} / \mathrm{m}$, and that of the $2 \mathrm{G}$ magnetometer about $3 \times 10^{-5} \mathrm{~A} / \mathrm{m}$. Stepwise demagnetization was completed using an independent static alternating field (AF) system in Oxford (up to 90 $\mathrm{mT}$ ), and using the AF system linked to the $2 \mathrm{G}$ magnetometer (for fields up to $60 \mathrm{mT}$ ) in Edinburgh, with a separate static system for fields up to $90 \mathrm{mT}$. Stable components were identified by principal component analysis. A parameter to reflect the quality of the data was assigned (Fig. 2; Table 1): $6=$ well-defined linear plots directed toward the origin; $5=$ less well-defined linear plots that trend to the origin; $4=$ well-defined linear plots that miss the origin, indicating the existence of a higher stability component; $3=$ less well-defined linear plots that miss the origin; 2 = stable magnetizations that do not demagnetize at the maximum field, or that demagnetize abruptly, with no linear plot being identified; 1 = plots with multiple components; and $0=$ unstable, random magnetizations.

Bedding was measured directly in the core, as described in Mascle, Lohmann, Clift, et al. (1996) and from minicubes, as apparent dips, and then converted to true dips and directions. Note that these measurements are often imprecise, particularly when bedding dips are low. MacLeod et al. (1994) have demonstrated that for apparent dips measured with a precision of $1^{\circ}$, the direction of bedding dip can be determined to a precision of better than $20^{\circ}$ for beds with true dips of $>4^{\circ}$. However, as the measurement of apparent dip becomes less precise, the true dip of beds whose azimuth can be deter- mined to a given precision increases rapidly; if the precision in the apparent dip is as poor as $5^{\circ}$ (probably the worst case encountered in this study), only beds with true dips of $>18^{\circ}$ could be measured with a precision of $>20^{\circ}$ in dip direction.

The Côte d'Ivoire-Ghana Transform Margin is currently at a latitude of $1^{\circ} \mathrm{N}$, and plate models (Scotese et al., 1988; Table 2) predict that it has remained close to equatorial latitudes for much of its history. The predicted inclinations for the magnetic field are subhorizontal, so that magnetic polarities cannot be established from inclination-only data.

The question of the age of the stable magnetization is paramount. Late remagnetizations may be used to reorient the core, but for no other useful purpose. The best way of establishing the relative age of the magnetization is by application of appropriate field tests, such as fold tests or tilt tests, for which a reoriented direction is generally required. The most appropriate method for independently reorienting the core comes from a comparison of measured dip in the core with the regional dip. FMS data from Hole 959D, between 550 and 860 mbsf, indicate bedding dips in the northwest quadrant, with a mode between $320^{\circ}$ and $330^{\circ}$. In Hole $960 \mathrm{C}$, most of the bedding measurements made are between $325^{\circ}$ and $352^{\circ}$. Seismic reflection data indicate that seismic stratigraphic units dip away from the marginal ridge adjacent to the transform, which strikes about $060^{\circ}$ (Mascle, Lohmann, Clift, et al., 1996). We therefore assume that the sediments determined from seismic sections and from the limited FMS data dip toward $330^{\circ}$. A small error in the choice of this regional dip direction would produce a small apparent rotation, below the resolution of this study. Paleomagnetic directions were restored to this nominal reference frame by an azimuthal correction.

This azimuthal correction involved a rotation about a vertical axis which will restore the bedding to a dip direction of $330^{\circ}$. This corresponds to the azimuthally corrected, pre-tilt corrected direction given in Table 1. The second correction applied is a standard bedding correction required to bring the bed (now dipping towards $330^{\circ}$ ) to a horizontal position. This corresponds to the azimuthally corrected, post-tilt corrected direction of Table 1 .

The sources of error in the corrected declination are threefold: (1) the normal errors associated with paleomagnetic measurement; (2) the errors in measurement of the bedding dip direction; and (3) the deviation of the local bedding direction from the regional direction. In comparison, the inclination data suffer only from errors associated with the paleomagnetic measurement. For this reason, it is important to consider the inclination data in isolation, as well as with the decli- 


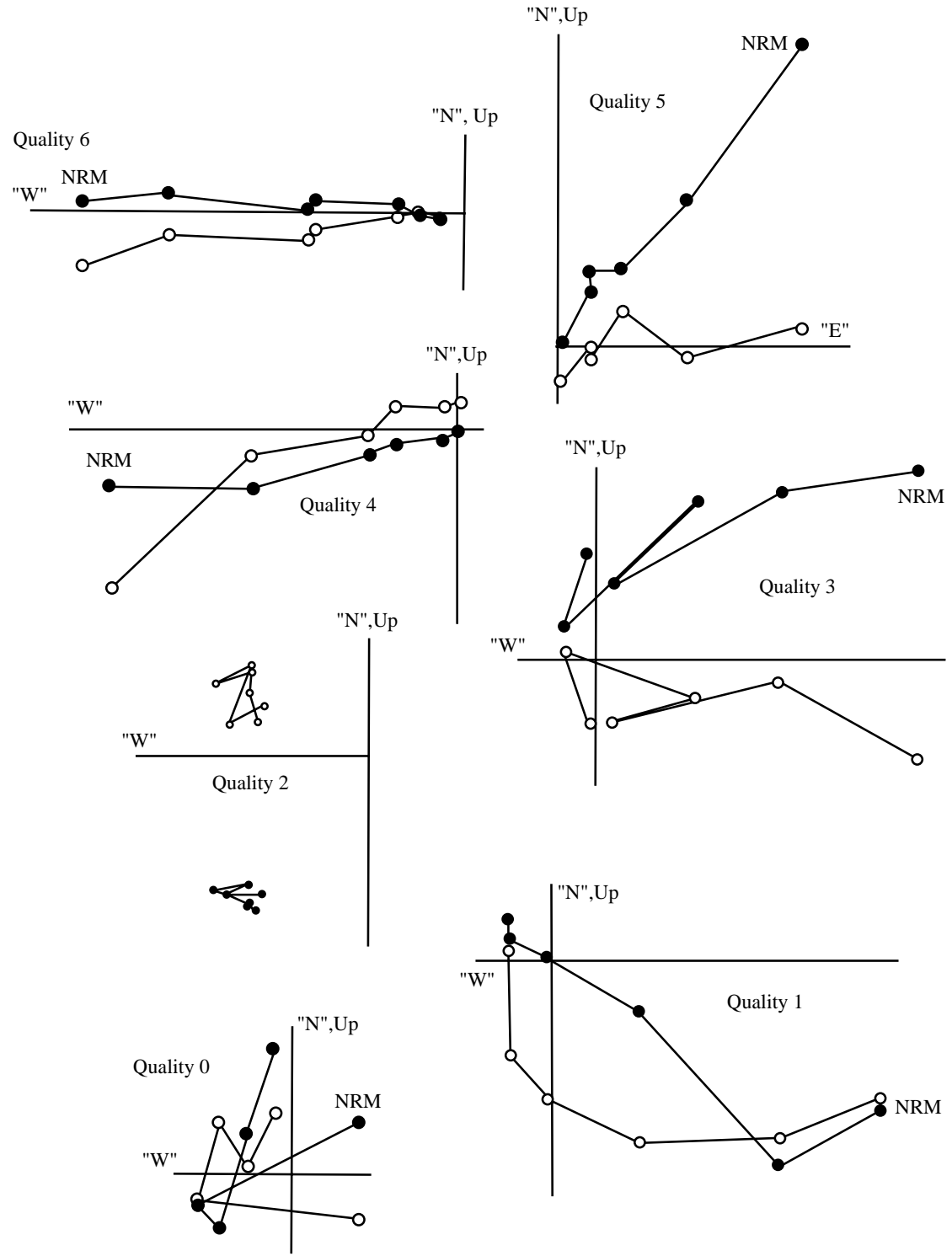

Figure 2. Orthogonal vector diagrams illustrating the types of demagnetization behavior characterized by the quality criteria used in Table 2 . Quality $6=$ welldefined linear plots directed towards the origin (159960A-45R-1, $44 \mathrm{~cm}$ ); 5 = less well-defined linear plots that trend to the origin (159-960A-52R-1, 145 $\mathrm{cm}) ; 4=$ well-defined linear plots that miss the origin, indicating the existence of a higher stability component (159-960A-54R-1, $27 \mathrm{~cm}) ; 3$ = less well-defined linear plots that miss the origin (159-960A-58R-2, 118 $\mathrm{cm}) ; 2$ = stable magnetizations that do not demagnetize at the maximum field, or that demagnetize abruptly, with no linear plot being identified (159959D-43R-4, $93 \mathrm{~cm}$ ); 1 = magnetizations with multiple components (159-959D-59R-4, $54 \mathrm{~cm})$; and $0=$ essentially random behavior (159-959D-62R-3, 60 nation data. This greater error in declination compared to inclination invalidates the assumptions inherent in the Fisher statistics (Fisher, 1953), so care needs to be used with these statistics. These corrections are only appropriate for those sites believed to have this regional dip. An additional approach was applied to Unit V of Hole 960A, which had been subjected to an earlier tectonic episode. This correction is described in detail in the appropriate section below.

For tectonic and magnetostratigraphic studies, it is necessary to compare the local paleomagnetic results with expected declinations and inclinations calculated from published paleopoles. In this study, we have used poles published by Westphal et al. (1986; Table 2).

\section{RESULTS AND INTERPRETATION}

Tectonic structures were largely confined to the deeper holes drilled during Leg 159. In the holes drilled using advance piston core (APC) methods, structures encountered in the cores were generally drilling induced and bedding dips were gentle. The ability to reorient the core using FMS and bedding dips required measurable dips, so this study concentrated on the holes drilled by rotary methods, in particular Holes 959D and 960A. The results will be discussed and inter- preted below, unit by unit. The actual measurements are shown in Table 1. A significant proportion of samples from both the holes were too weak to measure precisely, and certainly would be too weak to measure after demagnetization. No further destructive tests were applied to these samples, and they are not included in the data table.

\section{Hole 959D}

Hole 959D was drilled on the southern edge of the Deep Ivorian Basin, which is on the northern flank of the marginal ridge. Five main lithologic units were identified (Fig. 3). Units I through III (Holocene-early Coniacian) are mainly calcareous and siliceous basinal sediments. Unit IV (early Coniacian-early Turonian) are principally redeposited reef debris. Unit V (late Albian) are siliceous clastic sediments. There is an unconformity between Units IV and V. Paleomagnetic results are presented for samples from Units IIC, III, IVA and $\mathrm{V}$.

\section{Subunit IIC (Early Oligocene to Late Paleogene).}

This sequence of porcellanites with micrite and clay are in general weakly magnetized (with the exception of Sample 159-959D-13R-4, 
Table 1. Reliable paleomagnetic data from Holes 959D and 960A.

\begin{tabular}{|c|c|c|c|c|c|c|c|c|c|c|c|}
\hline \multirow[b]{3}{*}{ Sample } & & & & & & & & & Correct & directic & \\
\hline & & & & (c & re) & & core) & Befo & e tilt & Aft & tilt \\
\hline & Unit & $\begin{array}{c}\mathrm{NRM} \\
(\mathrm{mA} / \mathrm{m})\end{array}$ & $\begin{array}{c}\text { Quality } \\
(0-6)\end{array}$ & Decl. & Incl. & Dip & Direction & Decl. & Incl. & Decl. & Incl \\
\hline 159-959A- & & & & & & & & & & & \\
\hline $13 \mathrm{R}-4,13$ & IIC & 21.700 & 3 & 25 & 10 & & & & & & \\
\hline $28 \mathrm{R}-1,49$ & IIC & 0.048 & 2 & 356 & 62 & & & & & & \\
\hline $28 \mathrm{R}-7,34$ & IIC & 0.045 & 3 & 321 & 55 & & & & & & \\
\hline $29 \mathrm{R}-1,123$ & IIC & 0.021 & 2 & 334 & 56 & & & & & & \\
\hline $36 \mathrm{R}-1,17$ & IIC & 0.021 & 3 & 187 & -35 & & & & & & \\
\hline $41 \mathrm{R}-4,85$ & IIC & 0.027 & 3 & 267 & -54 & & & & & & \\
\hline $43 \mathrm{R}-4,35$ & III & 0.012 & 5 & 118 & 49 & 20 & 264 & 184 & 49 & 203 & 16 \\
\hline $43 \mathrm{R}-4,93$ & III & 0.058 & 2 & 223 & -19 & 20 & 260 & 293 & -19 & 299 & -35 \\
\hline $45 \mathrm{R}-4,56$ & III & 0.023 & 1 & & & & & & & & \\
\hline $46 \mathrm{R}-2,11$ & III & 0.025 & 2 & 105 & 67 & & & & & & \\
\hline $48 \mathrm{R}-1,109$ & III & 0.058 & 5 & 233 & 9 & 24 & 187 & 16 & 9 & 18 & 33 \\
\hline $52 \mathrm{R}-2,93$ & III & 0.025 & 1 & & & & & & & & \\
\hline $53 \mathrm{R}-6,21$ & III & 0.214 & 6 & 104 & 13 & & & & & & \\
\hline $54 \mathrm{R}-2,13$ & III & 0.025 & 3 & 201 & -10 & & & & & & \\
\hline $54 \mathrm{R}-2,67$ & III & 0.069 & 3 & 257 & 32 & & & & & & \\
\hline $54 \mathrm{R}-3,71$ & III & 0.179 & 6 & 98 & 34 & 22 & 319 & 109 & 34 & 97 & 52 \\
\hline $55 \mathrm{R}-2,30$ & III & 0.053 & 5 & 130 & 54 & & & & & & \\
\hline $55 \mathrm{R}-4,57$ & III & 0.057 & 3 & 33 & 67 & 20 & 180 & 183 & 67 & 182 & 47 \\
\hline $56 \mathrm{R}-3,111$ & III & 0.476 & 2 & 284 & -69 & 28 & 332 & 282 & -69 & 202 & -69 \\
\hline $56 \mathrm{R}-6,38$ & III & 0.018 & 5 & 275 & -1 & 47 & 225 & 20 & -1 & 11 & 41 \\
\hline $56 \mathrm{R}-6,95$ & III & 0.072 & 4 & 279 & 4 & 22 & 270 & 339 & 4 & 339 & -4 \\
\hline $57 \mathrm{R}-1,57$ & III & 0.037 & 2 & 263 & 38 & 16 & 108 & 125 & 38 & 122 & 23 \\
\hline $57 \mathrm{R}-1,78$ & III & 0.035 & 1 & 125 & 16 & 24 & 126 & 329 & 16 & 334 & 38 \\
\hline $57 \mathrm{R}-2,42$ & III & 0.026 & 3 & 152 & -56 & & & & & & \\
\hline $58 \mathrm{R}-3,86$ & III & 0.076 & 3 & 24 & 27 & & & & & & \\
\hline $58 \mathrm{R}-4,42$ & III & 0.029 & 2 & & & & & & & & \\
\hline $58 \mathrm{R}-4,51$ & III & 0.053 & 1 & 73 & 19 & 10 & 180 & 223 & 19 & 221 & 12 \\
\hline $59 \mathrm{R}-3,117$ & III & 0.061 & 5 & 128 & 48 & 8 & 150 & 308 & 48 & 303 & 55 \\
\hline $59 \mathrm{R}-4,54$ & III & 0.042 & 1 & & & 30 & 360 & & & & \\
\hline $59 \mathrm{R}-4,100$ & III & 0.030 & 3 & 66 & 57 & & & & & & \\
\hline $60 \mathrm{R}-3,40$ & III & 0.071 & 5 & 30 & 24 & 34 & 32 & 328 & 24 & 336 & 7 \\
\hline $60 \mathrm{R}-5,27$ & III & 0.075 & 2 & 273 & 7 & 39 & 200 & 43 & 7 & 52 & 41 \\
\hline $60 \mathrm{R}-5,62$ & III & 0.026 & 3 & 275 & 59 & & & & & & \\
\hline $61 \mathrm{R}-2,120$ & III & 0.045 & 1 & 117 & 55 & & & & & & \\
\hline $61 \mathrm{R}-3,66$ & III & 0.026 & 1 & 294 & -15 & 27 & 217 & 47 & -15 & 47 & 11 \\
\hline $62 \mathrm{R}-2,39$ & III & 0.026 & 2 & 130 & 86 & & & & & & \\
\hline $62 \mathrm{R}-2,145$ & III & 0.054 & 3 & 86 & 8 & 31 & 128 & 288 & 8 & 283 & 36 \\
\hline $63 \mathrm{R}-2,140$ & III & 0.166 & 5 & 181 & -32 & & & & & & \\
\hline $63 \mathrm{R}-4,29$ & III & 0.035 & 3 & 310 & 74 & 31 & 308 & 332 & 74 & 317 & 44 \\
\hline $64 \mathrm{R}-1,142$ & III & 0.041 & 3 & 279 & 1 & 25 & 349 & 260 & 1 & 260 & 1 \\
\hline $64 \mathrm{R}-4,7$ & III & 0.105 & 6 & 17 & 19 & 25 & 354 & 353 & 19 & 353 & -6 \\
\hline $65 \mathrm{R}-1,92$ & III & 0.060 & 1 & & & 15 & 109 & 221 & 0 & 220 & 6 \\
\hline $65 \mathrm{R}-5,113$ & III & 0.101 & 5 & 334 & 50 & 14 & 330 & 334 & 50 & 333 & 36 \\
\hline $66 \mathrm{R}-1,105$ & III & 0.057 & 4 & 189 & 64 & 15 & 172 & 347 & 64 & 341 & 79 \\
\hline $66 \mathrm{R}-2,17$ & III & 0.173 & 6 & 78 & 57 & 20 & 90 & 318 & 57 & 352 & 66 \\
\hline $67 \mathrm{R}-2,114$ & III & 0.213 & 5 & 338 & 37 & & & & & & \\
\hline $68 \mathrm{R}-1,68$ & IVA & 0.085 & 2 & 258 & 45 & 21 & 257 & 331 & 45 & 314 & 36 \\
\hline $74 \mathrm{R}-1,51$ & V & 0.296 & 3 & 323 & 26 & & & & & & \\
\hline $76 \mathrm{R}-1,69$ & $\mathrm{~V}$ & 0.337 & 3 & 96 & 11 & 39 & 5 & 61 & 11 & 61 & -11 \\
\hline 159-960A- & & & & & & & & & & & \\
\hline 10R-5, 90 & IB & 0.418 & 6 & 213 & 66 & & & & & & \\
\hline $11 \mathrm{R}-1,99$ & IB & 0.588 & 5 & 38 & 17 & & & & & & \\
\hline $12 \mathrm{R}-3,55$ & IB & 0.015 & 3 & 74 & 53 & & & & & & \\
\hline $15 \mathrm{R}-1,41$ & IIA & 0.030 & 3 & 28 & 72 & & & & & & \\
\hline $28 \mathrm{R}-2,52$ & IVB & 0.382 & 6 & 289 & -14 & & & & & & \\
\hline $29 \mathrm{R}-1,39$ & IVB & 0.054 & 1 & 215 & 18 & & & & & & \\
\hline $31 \mathrm{R}-1,83$ & IVB & 0.257 & 2 & & & & & & & & \\
\hline $32 \mathrm{R}-2,27$ & IVB & 0.298 & 5 & 328 & -6 & & & & & & \\
\hline $36 \mathrm{R}-1,102$ & IVB & 0.053 & 3 & 202 & -37 & & & & & & \\
\hline $37 \mathrm{R}-2,121$ & IVB & 1.181 & 3 & 197 & 85 & 80 & 272 & 255 & 85 & 325 & 9 \\
\hline $38 \mathrm{R}-1,24$ & IVB & 0.234 & 1 & 12 & 67 & 39 & 136 & 206 & 67 & 292 & 59 \\
\hline $40 \mathrm{R}-1,20$ & IVB & 0.318 & 3 & 164 & 33 & 33 & 128 & 6 & 33 & 359 & 5 \\
\hline $43 \mathrm{R}-1,34$ & IVB & 0.011 & 6 & 314 & 17 & 8 & 300 & 344 & 17 & 344 & 9 \\
\hline $44 \mathrm{R}-1,60$ & IVB & 0.125 & 5 & 65 & 14 & 27 & 53 & 342 & 14 & 342 & -12 \\
\hline $44 \mathrm{R}-3,4$ & IVB & 0.4 & 4 & 93 & -15 & 90 & 90 & 333 & -15 & 139 & -75 \\
\hline $45 \mathrm{R}-1,124$ & IVB & 0.283 & 6 & 82 & 0 & 16 & 72 & 340 & 0 & 340 & -15 \\
\hline $45 \mathrm{R}-1,44$ & IVB & 0.243 & 6 & 304 & 6 & & & & & & \\
\hline $45 \mathrm{R}-2,104$ & IVB & 0.311 & 6 & 239 & 26 & 67 & 89 & 120 & 26 & 48 & 63 \\
\hline 46R-2, 19 & IVB & 0.766 & 4 & 25 & 49 & 13 & 68 & 287 & 49 & 295 & 39 \\
\hline $46 \mathrm{R}-2,52$ & IVB & 1.061 & 2 & 87 & 15 & 15 & 33 & 24 & 15 & 22 & 6 \\
\hline $47 \mathrm{R}-1,65$ & IVB & 0.325 & 6 & 85 & 6 & 26 & 56 & 359 & 6 & 0 & -17 \\
\hline $47 \mathrm{R}-1,99$ & IVB & 0.231 & 4 & 58 & 20 & & & & & & \\
\hline $49 \mathrm{R}-1,102$ & IVB & 0.327 & 6 & 201 & 14 & 37 & 200 & 331 & 14 & 331 & -23 \\
\hline 49R-CC, 6 & IVB & 0.286 & 6 & 341 & -12 & & & & & & \\
\hline $52 \mathrm{R}-1,145$ & IVB & 0.156 & 5 & 310 & -4 & 10 & 253 & 27 & -4 & 28 & -10 \\
\hline $54 \mathrm{R}-1,135$ & VB & 0.445 & 6 & 126 & 18 & 40 & 214 & 184 & 18 & 203 & 48 \\
\hline $54 \mathrm{R}-1,27$ & VB & 0.258 & 4 & 255 & 15 & 40 & 201 & 11 & 15 & 11 & -16 \\
\hline $54 \mathrm{R}-3,47$ & VB & 0.235 & 6 & 189 & 14 & 26 & 0 & 318 & 14 & 318 & -12 \\
\hline $54 \mathrm{R}-3,71$ & VB & 0.179 & 6 & 98 & 34 & & & & & & \\
\hline $56 \mathrm{R}-1,116$ & VB & 0.374 & 5 & 320 & -3 & 9 & 296 & 354 & -3 & 354 & -11 \\
\hline
\end{tabular}


Table 1 (continued).

\begin{tabular}{|c|c|c|c|c|c|c|c|c|c|c|c|}
\hline \multirow[b]{3}{*}{ Sample } & \multirow[b]{3}{*}{ Unit } & \multirow{3}{*}{$\begin{array}{c}\mathrm{NRM} \\
(\mathrm{mA} / \mathrm{m})\end{array}$} & \multirow{3}{*}{$\begin{array}{c}\text { Quality } \\
(0-6)\end{array}$} & \multirow{2}{*}{\multicolumn{2}{|c|}{$\begin{array}{l}\text { Magnetization } \\
\text { (core) }\end{array}$}} & \multirow{2}{*}{\multicolumn{2}{|c|}{$\begin{array}{l}\text { True Dip } \\
\text { (core) }\end{array}$}} & \multicolumn{4}{|c|}{ Corrected direction } \\
\hline & & & & & & & & \multicolumn{2}{|c|}{ Before tilt } & \multicolumn{2}{|c|}{ After tilt } \\
\hline & & & & Decl. & Incl. & Dip & Direction & Decl. & Incl. & Decl. & Incl. \\
\hline $56 \mathrm{R}-1,96$ & VB & 0.334 & 6 & 89 & 2 & 5 & 307 & 112 & 2 & 112 & 6 \\
\hline $57 \mathrm{R}-1,119$ & VB & 0.416 & 3 & 196 & -22 & 12 & 228 & 219 & -22 & 215 & -17 \\
\hline $57 \mathrm{R}-1,33$ & VB & 0.421 & 5 & 25 & 23 & 15 & 289 & 127 & 23 & 123 & 37 \\
\hline 57R-2, 79 & VB & 0.282 & 6 & 284 & -14 & 12 & 48 & 325 & -14 & 325 & -26 \\
\hline $58 \mathrm{R}-1,77$ & VB & 0.268 & 6 & 342 & 0 & 6 & 315 & 264 & 0 & 264 & -2 \\
\hline $58 \mathrm{R}-2,118$ & VB & 0.201 & 3 & 331 & 11 & 4 & 284 & 346 & 11 & 346 & 7 \\
\hline $58 \mathrm{R}-2,122$ & VB & 0.154 & 6 & 333 & 17 & 15 & 360 & 19 & 17 & 17 & 7 \\
\hline $58 \mathrm{R}-3,1$ & VB & 0.296 & 6 & 325 & -11 & 12 & 66 & 295 & -11 & 293 & -21 \\
\hline 58R-CC, 11 & VB & 0.26 & 6 & 231 & -2 & 10 & 287 & 135 & -2 & 135 & 8 \\
\hline $59 \mathrm{R}-1,28$ & VB & 0.541 & 4 & 26 & -5 & 5 & 338 & 69 & -5 & 70 & $\begin{array}{r}0 \\
-4\end{array}$ \\
\hline $59 \mathrm{R}-1,99$ & VB & 0.822 & 1 & 72 & -34 & 5 & 320 & 64 & -34 & 67 & -34 \\
\hline 59R-2, 8 & VB & 0.455 & 6 & 254 & 5 & 3 & 45 & 264 & 5 & 264 & 4 \\
\hline $59 \mathrm{R}-2,83$ & VB & 0.325 & 3 & 51 & 16 & 11 & 100 & 336 & 16 & 336 & 5 \\
\hline $59 \mathrm{R}-3,41$ & VB & 0.863 & 3 & 322 & -26 & 12 & 130 & 192 & -26 & 189 & -17 \\
\hline $60 \mathrm{R}-1,65$ & VB & 0.343 & 3 & 234 & 20 & 13 & 296 & 74 & 20 & 69 & 23 \\
\hline $60 \mathrm{R}-2,67$ & VB & 0.731 & 3 & 358 & 13 & 8 & 353 & 32 & 13 & 31 & 9 \\
\hline $60 \mathrm{R}-2,52$ & VB & 0.751 & 4 & 83 & 8 & & & & & & \\
\hline $61 \mathrm{R}-1,106$ & VB & 2.349 & 4 & 272 & 23 & 9 & 116 & 242 & 23 & 246 & 22 \\
\hline $61 \mathrm{R}-1,125$ & VB & 0.506 & 3 & 67 & 30 & 21 & 41 & 281 & 30 & 287 & 15 \\
\hline $61 \mathrm{R}-2,29$ & VB & 0.697 & 4 & 175 & 3 & 11 & 350 & 104 & 3 & 103 & 11 \\
\hline
\end{tabular}

Notes: The quality factor and correction applied to the stable paleomagnetic directions are described in the text (with examples in Fig. 2). Data with a quality factor of 0 have not been included in this table. Decl. = declination; Incl. = inclination.

Table 2. African paleopoles and expected field directions at $3^{\circ} \mathrm{N}, 3^{\circ} \mathrm{W}$.

\begin{tabular}{|c|c|c|c|c|}
\hline \multirow[b]{2}{*}{ Interval } & \multicolumn{2}{|c|}{ Pole } & \multicolumn{2}{|c|}{ Site } \\
\hline & ${ }^{\circ} \mathrm{N}$ & ${ }^{\circ} \mathrm{E}$ & Incl. & Decl. \\
\hline Quaternary & 86 & 150 & -1 & 2 \\
\hline Pliocene & 86 & 160 & -2 & 1 \\
\hline Miocene & 83 & 163 & -8 & 2 \\
\hline Oligocene & 84 & 170 & -6 & 1 \\
\hline Paleocene-Eocene & 76 & 199 & -19 & 355 \\
\hline L. Cretaceous-Paleocene & 74 & 209 & -20 & 351 \\
\hline L. Cretaceous & 69 & 230 & -19 & 343 \\
\hline M. Cretaceous & 60 & 248 & -13 & 332 \\
\hline E. Cretaceous & 56 & 248 & -16 & 328 \\
\hline L. Jurassic-L. Cretaceous & 56 & 246 & -17 & 328 \\
\hline
\end{tabular}

Note: Poles from Westphal et al. (1986). L. = Late; M. = mid; E. = Early.

$13 \mathrm{~cm}$ ), and do not yield reliable components on AF demagnetization. No reliable bedding measurements were obtained for these samples.

\section{Unit III (late Paleocene to early Coniacian).}

The black claystones of Unit III are, on first inspection, poor candidates for paleomagnetic study, as they have clearly experienced strongly reducing conditions, indicated by the abundant pyrite replacing organic matter. It is unlikely that original magnetites or hematites would have survived in these sediments, and magnetic carriers are likely to be magnetic sulphides (e.g., pyrrhotite). Natural remanent magnetization (NRM) intensities are moderately low $(<0.5 \mathrm{~mA} / \mathrm{m})$, but measurable. The quality of the components resolved is highly variable, but some apparently reliable data were measured.

Before correction for bedding dip, inclinations are positive, with a strong peak in the distribution between $0^{\circ}$ and $10^{\circ}$ (see Fig. 4). After correction, the inclinations have a bimodal distribution, with peaks of the distributions at about $0^{\circ}$ and $40^{\circ}$. Figure 5 shows the stable directions after an azimuthal correction to bring the dip direction to a common orientation has been applied, both before and after a correction for bedding dip. The low-confidence components (1-3) show a broadly random distribution, mainly in the lower hemisphere, perhaps reflecting the influence of a steeply inclined, drilling-induced remanence. The directions with greater confidence (4-6), shown with larger symbols, are predominantly north-directed, with variable inclinations. There is no clear change in scatter when a bedding cor-

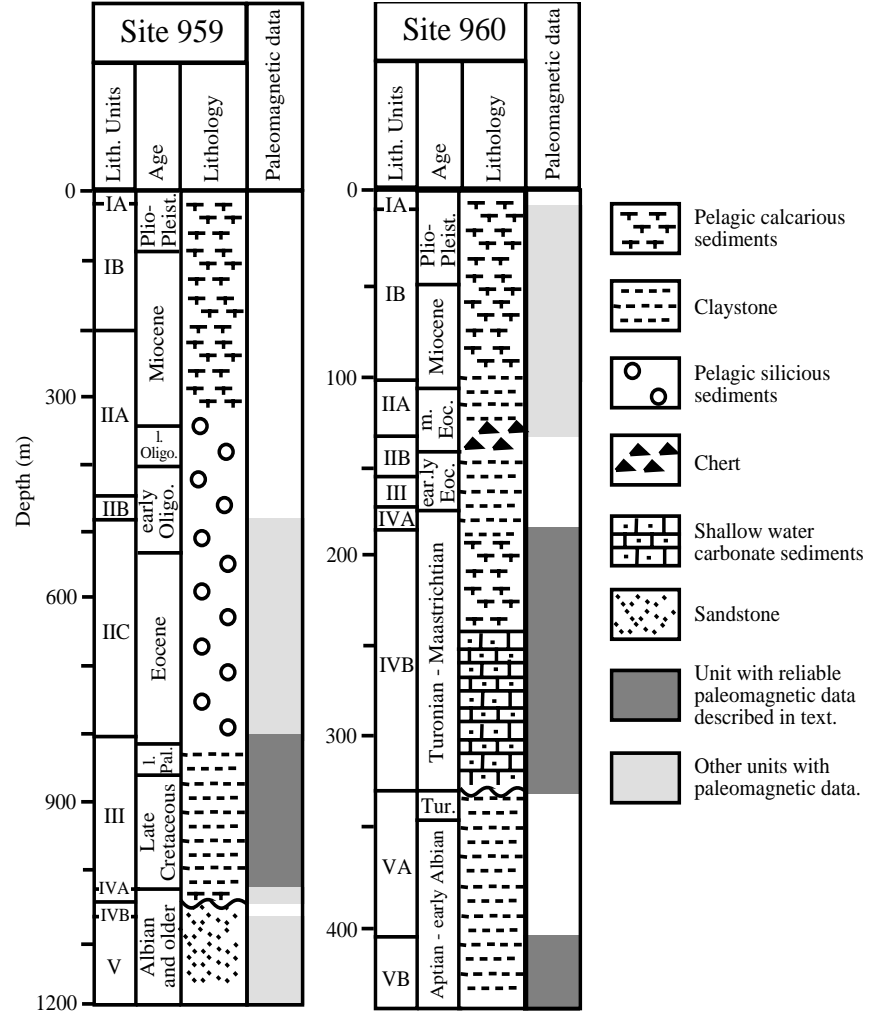

Figure 3. Simplified stratigraphic sections for Sites 959 and 960.

rection is applied. The steeper components may again be a drillinginduced magnetization. The shallower components are generally north-directed, without an antiparallel "reversed" cluster. They can be interpreted as either a recent remagnetization in the present, the normal field direction of the Earth, or an earlier magnetization in a normal field. Apart from confirming that the correction to bring the dip direction to the regional dip-direction is appropriate for at least some of the data, these results cannot be used to obtain any further geological information. 

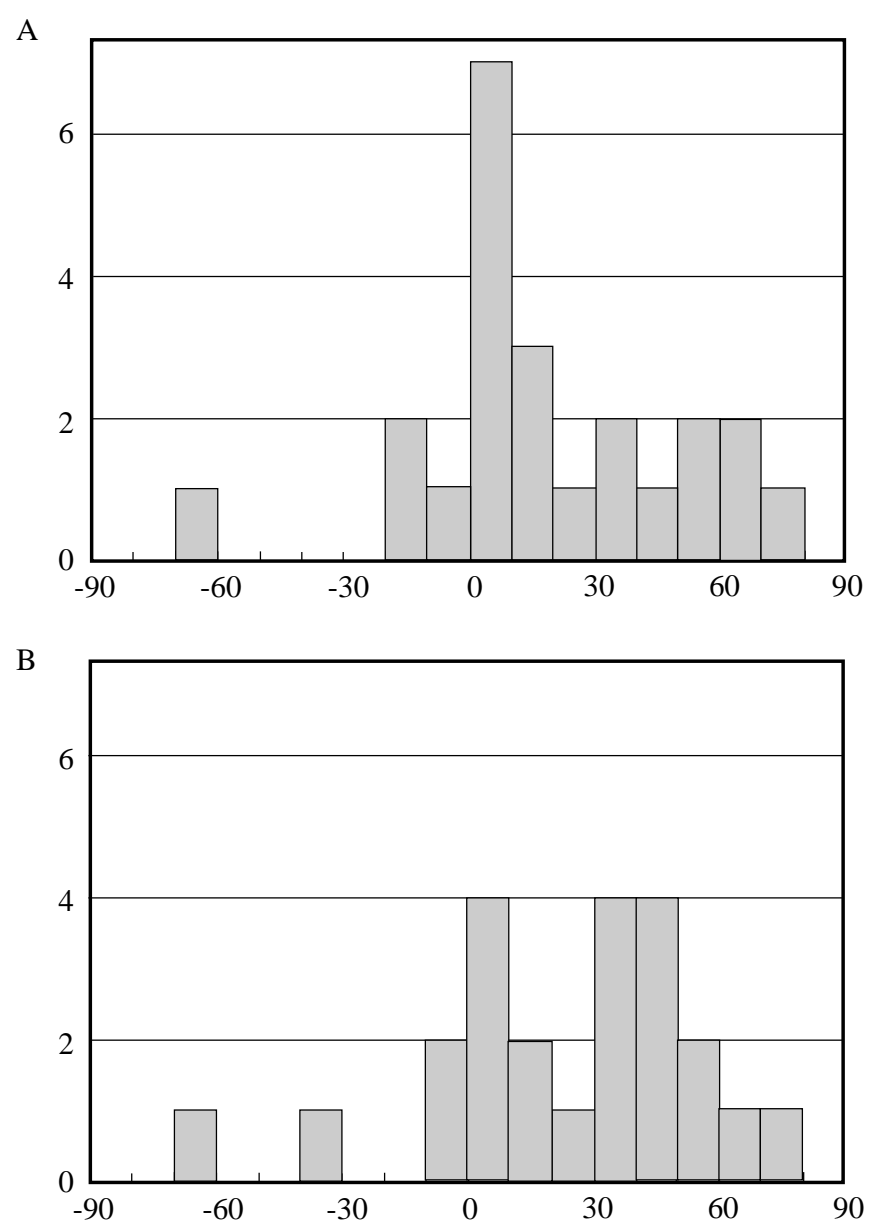

Figure 4. (Hole 959D, Unit III) Histogram of inclinations, before and after correction. A. Before correction. B. After correction.

\section{Subunit IVA (Early Coniacian to Early Turonian).}

Only one sample from the sandy limestones of Subunit IVA has been measured. It is weakly magnetized, and does not carry a reliable remanent component.

\section{Unit V (Late Albian)}

Four samples were taken from the quartz sandstones and silty claystones of Unit V. Of these, two yield components of poor reliability, but with relatively shallow inclinations both before and after tilt correction.

\section{Hole 960A}

This hole was drilled close to the crest of the marginal ridge, $3 \mathrm{mi}$ to the south of Site 959. Five lithologic units were identified in this hole. Units I-III are basinal, calcareous, and siliceous sediments. The sediments of Unit IV are hardground facies and redeposited reefal debris. The contact between Unit IV and the siliciclastic sediments of Unit $\mathrm{V}$ is an angular unconformity. We were able to obtain paleomagnetic results from Subunits IVB and VB, reported here.

\section{Subunit IVB (Coniacian to Turonian).}

The sandy limestones of Subunit IVB are relatively strongly magnetized, with NRM values up to about $3.5 \mathrm{~mA} / \mathrm{m}$. A high proportion

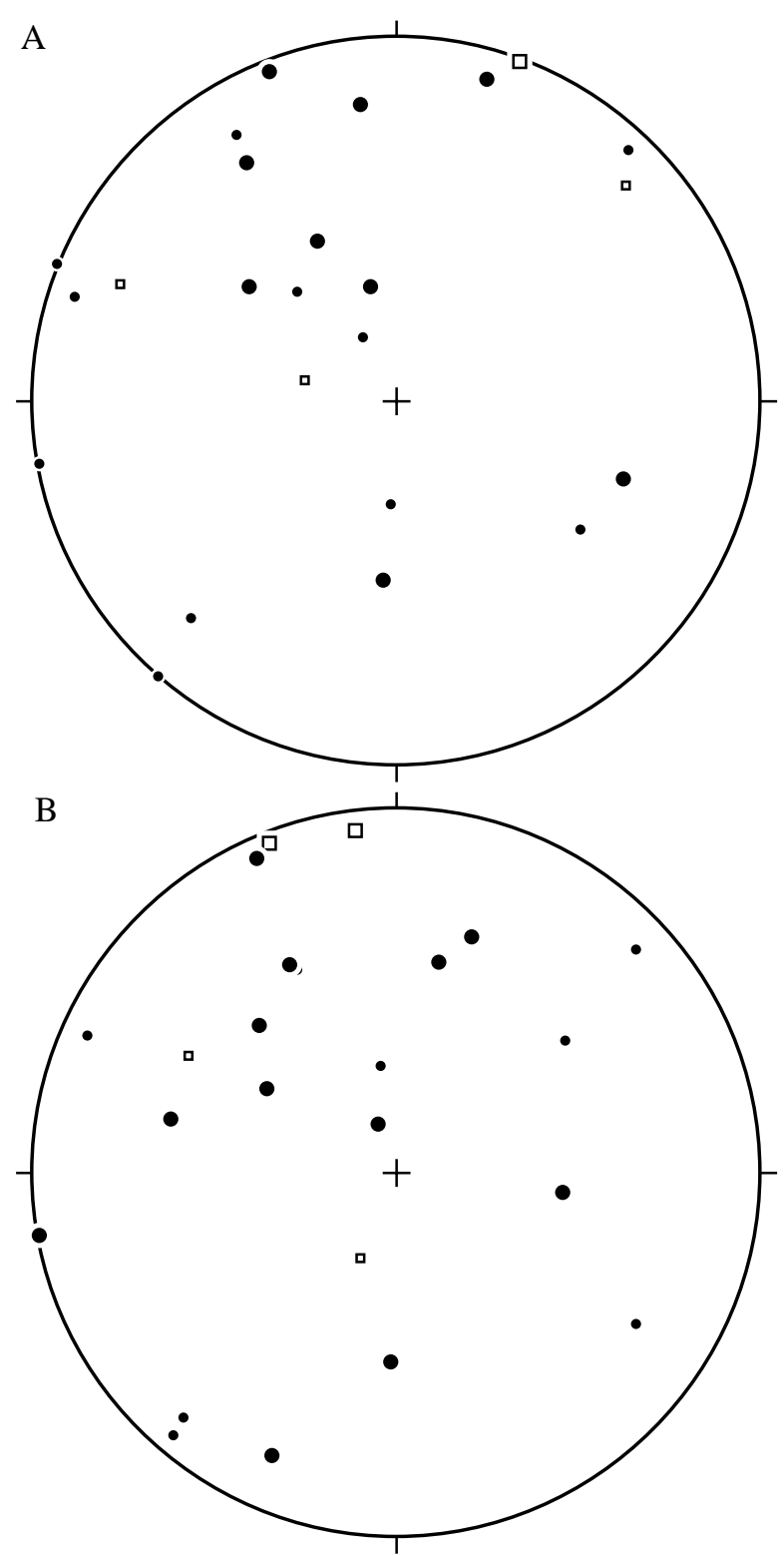

Figure 5. (Hole 959D, Unit III) Stereographic projection of stable components of magnetization. Open squares $=$ upper hemisphere, Solid circles $=$ lower hemisphere, large symbols $=$ reliable components (quality factor 4 to 6), small symbols = quality (0 to 3 ). A. Before correction. B. After correction.

of samples carry a stable remanence. Before any bedding correction is applied, the inclinations are fairly evenly distributed, between $-20^{\circ}$ and $90^{\circ}$ (Fig. 6). After application of a correction for bedding, the scatter is marginally improved, and inclinations are distributed between $-80^{\circ}$ and $70^{\circ}$, and centered about the predicted inclination of $0^{\circ}$. When the correction for bedding strike is applied (Fig. 7), the data cluster around a northerly direction, both before and after bedding correction, and no clear change in scatter is observed on application of the correction.

Therefore, we cannot discriminate between an early magnetization that predates tilting and a later, possibly recent, post-tilting magnetization. The correction for the strike of the beds produces a scatter that is non-random, suggesting that it is an appropriate correction to apply, and might be made to correct structural data in the core. 

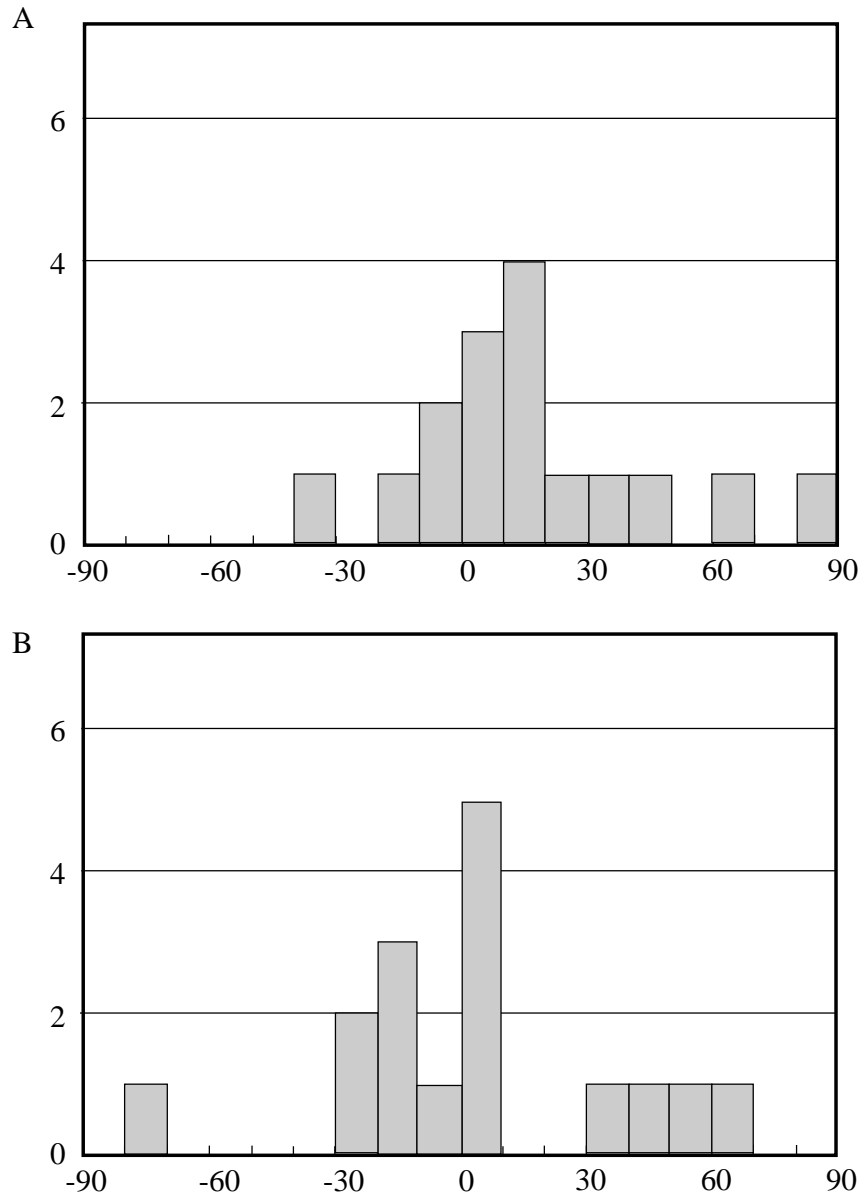

Figure 6. (Hole 960A, Subunit IVB) Histogram of inclinations, before and after correction. A. Before correction. B. After correction.

\section{Subunit VB (Unknown, Turonian or Older).}

Subunit VB is a sequence of siliciclastic rocks that is beneath a distinct angular unconformity. Bedding varies between $5^{\circ}$ and $60^{\circ}$ in Unit V, although the steepest dips are encountered immediately beneath the unconformity. Faults, both normal, reversed and strike-slip, are also common throughout Unit V. The rocks of Subunit VB are generally well magnetized, with NRM values $>0.1 \mathrm{~mA} / \mathrm{m}$. In all the samples a stable component of magnetization could be identified. Before bedding correction, the inclinations occurred between $-40^{\circ}$ and $40^{\circ}$, with a mean value of $5^{\circ}$ (Fig. 8A). After correction for bedding, the inclinations are between $-40^{\circ}$ and $50^{\circ}$ (Fig. 8B), with a mean of $4^{\circ}$; both close to the predicted paleo-inclination for rocks of the Cretaceous to Holocene age.

This sequence occurs beneath a significant unconformity, so a simple correction that brings dip direction to a constant orientation may not be appropriate. For these rocks, a more appropriate approach may be to assume a common declination (arbitrarily directed north) and then to determine the corrected apparent dip direction. For most of these samples, the bedding dips are $<15^{\circ}$, and under such circumstances the dip direction is poorly defined.

I have adopted both of these methods of reorienting the data. The first approach, to correct to a common bedding dip direction (Fig. 9), produces a high degree of scatter, both before and after a correction for bedding tilt has been applied.

The second approach, to reorient the bedding, assuming that all the magnetizations were directed north, produces an interesting result (Fig. 10). There is a large degree of scatter in the gently dipping beds,
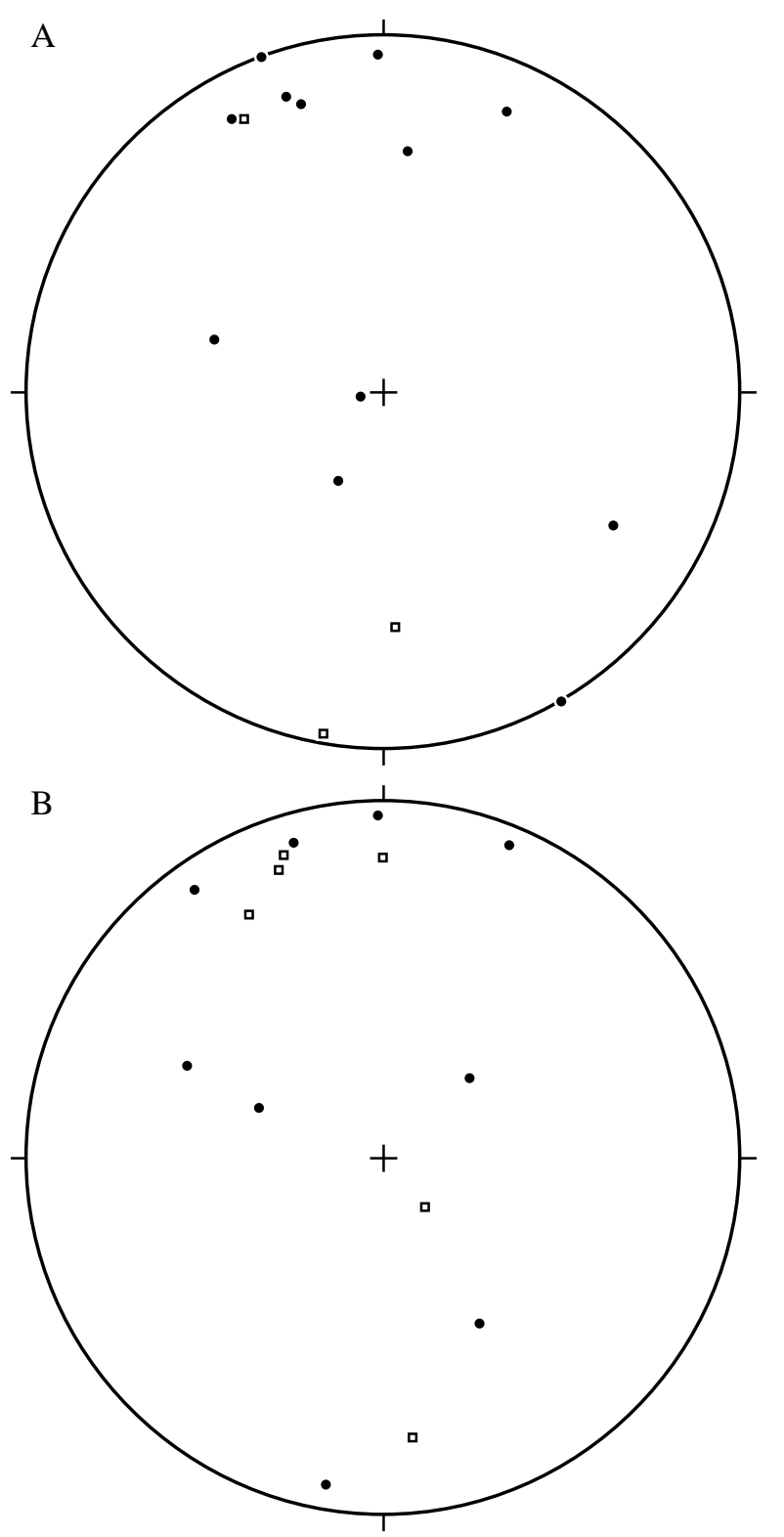

Figure 7. (Hole 960A, Subunit IVB) Stereographic projection of stable components of magnetization. Open squares $=$ upper hemisphere, solid circles $=$ lower hemisphere. A. Before correction. B. After correction.

but the few steeper beds have a common strike, directed toward $140^{\circ}$ (orthogonal to the orientation of the marginal ridge), but dip both toward north-northwest and south-southwest. This is the case if the beds are reoriented using either a declination before or after correction.

This result may reflect folding or tilting by faulting about an axis parallel to the marginal ridge, although because it is based on so few data, little weight can be placed on this result. We also cannot discriminate between early or late magnetizations.

\section{DISCUSSION}

For the section above the ?Turonian unconformity, the most appropriate correction for structural data is to rotate the bedding dip direction to a common regional azimuth. In this study, this was as- 

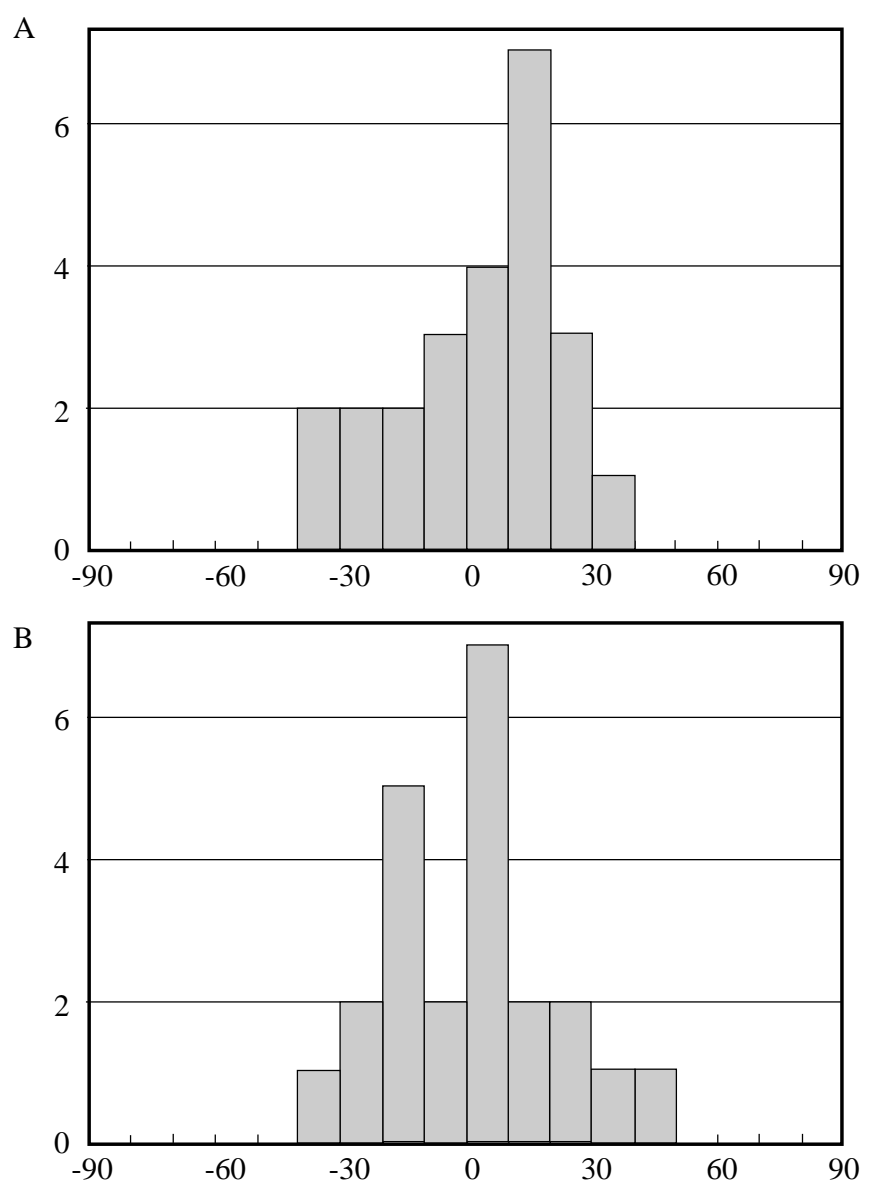

Figure 8. (Hole 960A, Subunit VB) Histogram of inclinations, before and after correction. A. Before correction. B. After correction.

sumed to be $330^{\circ}$, which was based on limited FMS data and regional seismic data approximately orthogonal to the marginal ridge. In this study, the resultant corrected magnetic declinations are approximately northerly, so the data do not support arguments for any vertical axis rotations between the Turonian time and the present.

In Unit III of Hole 959D the stable components record a gently dipping, north-directed magnetization. The relative age of this component with respect to the tilting history cannot be determined. The late Paleocene-early Coniacian age assigned to Unit III is a predominantly, but not exclusively, normally magnetized interval, quite consistent with the observation of all normal magnetizations for this section, although the magnetic components could equally result from a recent normal overprint.

In Subunit IVB of Hole 960A, the magnetizations are dominantly directed to the north, and there is no significant subhorizontal, southdirected component. This result is consistent with a component formed either as a recent remagnetization, or as an early, ConiacianTuronian magnetization in the Cretaceous normal polarity superchron.

In the section beneath the unconformity in Hole 960A, the results can be interpreted as either an early or a recent magnetization. This Unit is believed to be part of the rift-transform sequence, and as such to have formed between Neocomian and Albian times, an interval dominated by the Cretaceous normal-polarity superchron. The identification of a clear reversed interval would place the age at the earliest Aptian or earlier. The results from this sequence are ambiguous, and can either be interpreted as both normally and reversely magnetized directions, or a folded sequence of normally magnetized rocks. Given the clear evidence for folding and tilting on a local scale within

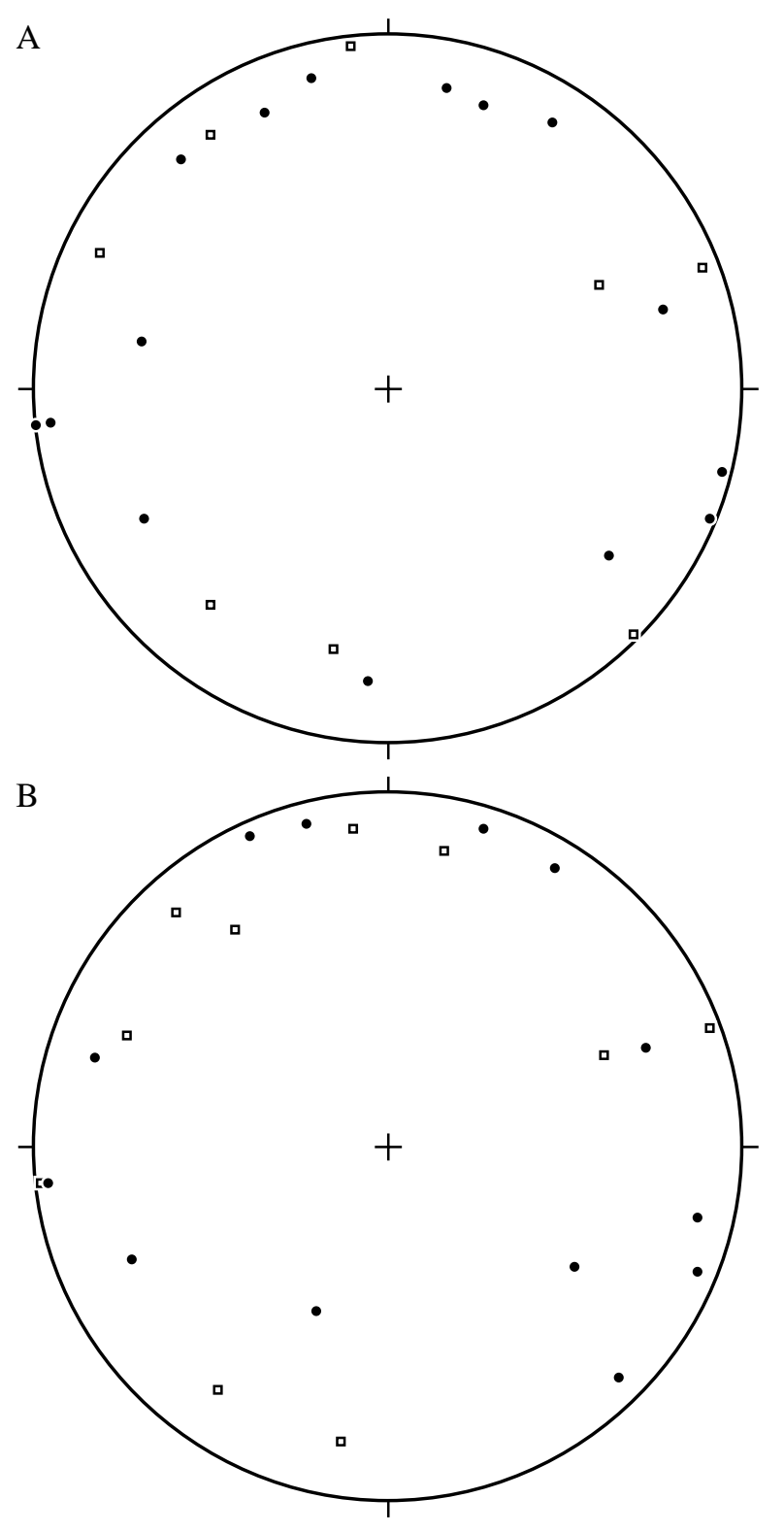

Figure 9. (Hole 960A, Subunit VB) Stereographic projection of stable components of magnetization. Open squares $=$ upper hemisphere, Solid squares $=$ lower hemisphere. A. Before correction. B. After correction.

the core, I tend to favor the latter option. This would be consistent with an Aptian-Albian age for Unit V.

\section{REFERENCES}

Blarez, E., and Mascle, J., 1988. Shallow structure and evolution of the Ivory Coast and Ghana transform margin. Mar. Pet. Geol., 5:54-64.

Emery, K.O., Uchupi, E., Phillips, J., Bowin, C., and Mascle, J., 1975. Continental margin off Western Africa: Angola to Sierra Leone. AAPG Bull., 59:2209-2265.

Fisher, R.A., 1953. Dispersion on a sphere. Proc. R. Soc. London A, 217:295-305.

Luyendyk, B.P., Kamerling, M.J., Terres, R.R., and Hornafius, J.S., 1985. Simple shear of Southern California during Neogene time suggested by paleomagnetic declinations. J. Geophys. Res., 90:12454-12466.

MacLeod, C.J., Parson, L.M., and Sager, W.W., 1994. Reorientation of cores using the Formation MicroScanner and Borehole Televiewer: application to structural and paleomagnetic studies with the Ocean Drilling Program. 
In Hawkins, J., Parson, L., Allan, J., et al., Proc. ODP, Sci. Results, 135: College Station, TX (Ocean Drilling Program), 301-311.

Mascle, J., Guiraud, M., Basile, C., Benkhelil, J., Bouillin, J.P., Cousin, M., and Mascle, G., 1993. La marge transformante de Côte d'Ivoire-Ghana: premiers résultats de la campagne Equanaute (Juin 1992) [The Côte d'Ivoire-Ghana transform margin: preliminary results from the Equanaute cruise (June 1992)]. C. R. Acad. Sci. Ser. 2, 316:1255-1261.

Mascle, J., Lohmann, G.P., Clift, P.D., et al., 1996. Proc. ODP, Init. Repts., 159: College Station, TX (Ocean Drilling Program).

Ron, H., Aydin, A., and Nur, A., 1984. Block rotation by strike-slip faulting: structural and paleomagnetic evidence. J.Geophys. Res., 89:6256-6270.

Scrutton, R.A., 1979. On sheared passive continental margins. Tectonophysics, 59:293-305.
Scotese, C.R., Gahagan, L.M., and Larson, R.L., 1988. Plate tectonic reconstructions of the Cretaceous and Cenozoic ocean basins. Tectonophysics, 155:27-48.

Westphal, M., Bazhenov, M.L., Lauer, J.P., Pechersky, D.M., and Sibuet, J.C., 1986. Paleomagnetic implications on the evolution of Tethys Belt from the Atlantic Ocean to the Palmirs since the Triassic. Tectonophysics, $123: 37-82$.

Date of initial receipt: 16 September 1996

Date of acceptance: 12 March 1997

Ms 159SR-045
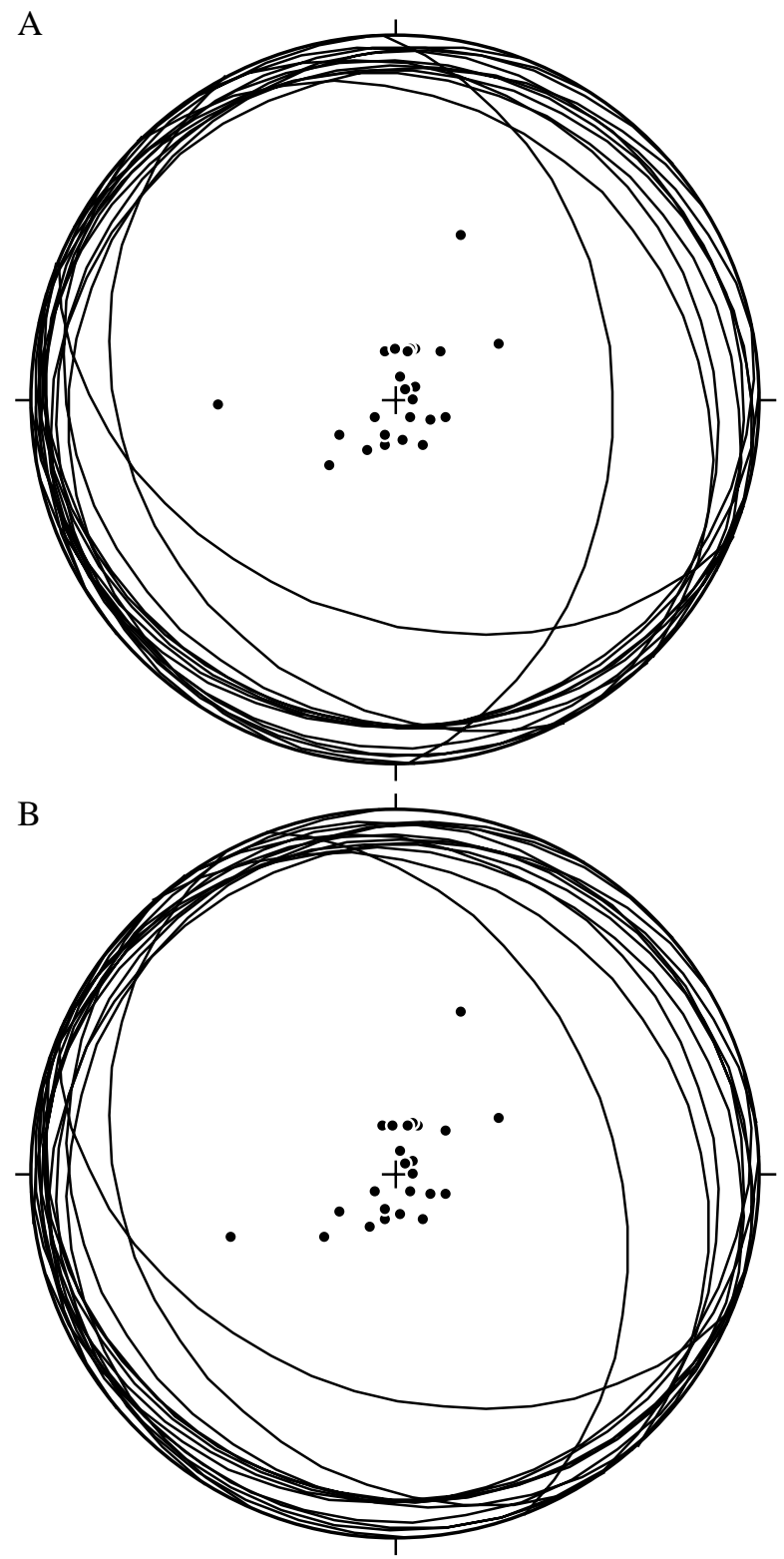

Figure 10. Hole 960A, Subunit VB. Stereographic projection of bedding planes, and poles to bedding after correction to bring stable component of magnetization to north. A. Before correction. B. After correction. 